\title{
Role of Government Interest Sarereiket Hold in Village in District Madobag Mentawai Islands
}

\author{
Sayid Anshar \\ Universitas Ekasakti Padang, Padang, Indonesia \\ email: ancasaid14@gmail.com
}

\begin{abstract}
The problem in this study is How the Sarereiket Tribe Role in organizing Government in the Village of Madobag Mentawai Islands District. The purpose of this study was to determine the Role of the Sarereiket Tribe in organizing Government in Madobag Village, Mentawai Islands Regency. This study uses qualitative and descriptive methods. In this study, the population is Madobag village apparatus, village representative body (BPD), hamlets, tribal organizations, community shops and Madobag village community environment. The sample in this study is Madobag village apparatus six people, one village representative body (BPD), three hamlet heads, two community shops and two people in the Madobag village environment. with purposive sampling technique. Based on the results of this study it is suggested that to realize good leadership at the village level, the village head must play a greater role in every village administration activity that concerns the public interest and is clearer in making decisions and being fair and being consistent in carrying out decisions especially in Sarereiket tribal governance in the village of Madobag.
\end{abstract}

Keywords-Role of the Sarereiket Tribe, Village Government.

\section{INTRODUCTION}

Customaryis cultural behavior or rules that have been tried to be applied in the community. Customs are a set of social rules that have long existed, and have become a habit (tradition) in society. Likewise with thetribe Sarereiket is a group of people who live and settle in thear chipelago Mentawai, West Sumatra province. Sarereiket tribes live in the Siberut area southern for generations.tribes Sarereiket live modestly in a remote area.tribe Sarereiket also believes the leaves become a liaison between the creator and humans, so strong the trust of thetribe Sarereiket to the power of abstinence for Sarereiket descendants to sukus destroy the forest, they are prohibited from cutting down the forest carelessly, based on the teachings of the ancestors mentawai leaves are believed to be the place where forest godsgods, mountain, sea gods, as well as water gods [1].

With Act Number 8 of 2005 concerning amendments to Law No. 32 of 2004 concerning local government recognizes the autonomy owned by the Village which is implemented in theRegency Mentawai Kepulawanto date has progressed in various aspects of community and government life [2]. With the enactment of Law No. 8/2005, it is about regional government which includes creating a system of government that is autonomous which 
implies efforts to regrow democracy and autonomy in society, especially in people who are in villages [3].

Based on the background above, it is interesting to do research on "The Role of the Sarereiket Tribe in Organizing Government in the Madobag Village, Mentawai Islands Regency"

\section{METHOD}

In this study the authors used qualitative research methods. Qualitative method is a method of social science to produce or obtain information from the situation and see the relationship of the variables examined. According to Maleong, research qualitative is an approach to look for patterns, principles that underlie the manifestation of the symptoms that exist, the symptoms are seen from the unity that each can not stand alone remain in touch with each other.

\section{RESULTS AND DISCUSSION}

A. The Role of theIndigenous SarereiketTribe in the Administration of the Village Government at the Madobag Village Office in the Mentawai Islands Regency.

In the administration of Madobag village government, the tribe has an important role because of the reality of the community that the community is experiencing powerlessness that is the community's inability related to the inability to come up with initiatives / ideas to develop themselves, inability to carry out development independently, and the inability to cooperate with theworld outside.

The role of the tribe in the village administration makes the community hang their hopes on the tribe because the tribe is one of the reservoirs of community aspirations which is then conveyed by the village government. For this reason, the tribe has a very important role in the administration of thevillage government Madobagbecause with the existence of the village government, the community will easily resolve the problems or problems that exist in thecommunity Madobag village. In providing services to the community, it is very necessary to have the role of the tribe to facilitate the village government in coordinating all the interests of the community, namely [4]:

1. The tribe has a role in village governance in terms of providing guidance and assistance as well as community motivation to participate in the implementation of activities involving interests together to build a better life.

2. Village and tribal governments alike try to improvedevelopment communityby providing training in agriculture and fisheries. The tribe also participates in motivating in the field of education such as

IJoASER,Volume 2,Issue 3, November, 2019

DOI: 10.33648/ijoaser.v2i2.37

Copyriht: STAI Al-Furqan Makassar,Indonesia

Content License: CC-BY-SA 
proposing scholarships to students in the hope that Madobag village communities can utilize and develop their own natural resources to develop thevillage area Madobag. The tribe is a representative institution which is a working partner of the village government. Its role and function is to support governance, traditional preservation, legislation, supervision, and to accommodate and channel the aspirations of the community.

We know that the village head as the leader of the village administration has the duty and obligation as government administration, the implementation of development and Trustees of community life as well as mental construct community in cultivate the spirit build in jiwai by the principle together and family strongtend to be oriented vertically which is oriented to the its leader. Therefore, if the village head wishes to implement good governance, the role of the clan is included as a partner of the village administration

\section{CONCLUSION}

Based on the results of field research that, the role of the tribe in the village administration makes the community hang their hopes on the tribe because the tribe is one of the reservoirs of community aspirations which is then conveyed by the village government. For this reason, the tribe has a very important role in the administration of the Madobag village government because with the existence of the village government, the community will easily resolve the problems or problems that exist in the Madobag village community.

\section{REFERENCES}

[1] Hernawati, Tarida S.2014, Sarereiket tribal forest school: publisher ofimagery foundation

[2] Mentawai independent MC Ricklefs, 2005, Sejara Indonesia Modren 1200-2004, Publisher, Veranda

[3] Stefano Coronese S., 1986, Culture of the Mentawai Tribe, Jakarta, Grafidia Jaya http: // Green fields. Blogspot. Com / 2010 / Regarding thetribe more Mentawai accessible

[4] 1945 Constitution after Amendment of Law No.8 of 2005 concerning Amendment to Law No.32 of 2004 concerning Regional Government. 